\title{
Study on the ameliorating effect of aqueous extract of Moringa oleifera on Ganga water
}

\author{
D. K. Paul* \\ Department of Zoology, Patna University, Patna, India \\ Nitu Kumari \\ Department of Zoology, Patna University, Patna, India \\ Sumona Sanyal \\ Department of Zoology, Patna University, Patna, India \\ *Corresponding author. E-mail: dkpaul.pat31@gmail.com
}

\begin{abstract}
The quality of surface water is deteriorating day by day due to various anthropogenic activities. Ganga water is assumed polluted almost in the entire strech of river. The medicinal plants may be useful for amelioration of pollution. The present work deals with the study of several chemical characteristics as well as microbial examination of water samples taken from few sites of Ganga river namely Krishna Ghat, Kali Ghat and N.I.T Ghat (Gandhi Ghat) at Patna. The study was foccused on the evaluation of antimicrobial effect of Moringa oleifera (sahjan) leaves extract in the Ganga water. The aqueous leaves extract of different concentrations $(0.1 \%, 0.16 \%, 0.23 \%, 0.3 \%)$ showed ameliorating results on $\mathrm{pH}$ and chloride content of water as well as microbial activity. Significant ameliorating results were observed on $\mathrm{pH}$ and chloride content of water. $\mathrm{pH}$ was reduced from 8.1 to 7.4 and chloride was reduced from $82.36 \mathrm{mg} / \mathrm{l}$ to $48.14 \mathrm{mg} / \mathrm{l}$ under plant extract treatment. Colony Forming Unit (CFU) was assessed by standard plate count (SPC) method and was found to be $468 \mathrm{CFU} / \mathrm{ml}$ for raw water, which was reduced to $143 \mathrm{CFU} / \mathrm{ml}$ when treated with plant extract. Similar decreasing trend was observed in case of MPN of coliform. So extract of Moringa oleifera may also be applied to purify drinking water. Morever it will be cheaper for the people in comparision to other purification devices.
\end{abstract}

Keywords: Drinking water, Ganga river, Moringa oleifera, Plant extract, Water pollution

\section{INTRODUCTION}

A sufficient supply of safe and sound drinking water is universally identified as a basic human need. Yet millions of people in developing countries defect even a basic drinking water service. In that situation water occurring in ponds, lakes, rivers and streams are used for drinking and domestic purposes (Fetter, 2011 and Iscen et al. 2008). These water bodies are usually polluted and contaminated with microorganisms that cause many diseases (Sood et al. 2008). The reasons behind poor water quality of Ganges River at Patna are sewage disposal, animal bathing, cloth washing, idol immersion and high silt discharge (Jaiswal et al. 2017). Consumption of contaminated fresh water is a major cause of waterborne diseases and when it is used for the food preparation, cause food borne diseases (Willey et al., 2008). Most of the water borne diseases still remains one of the major reasons of morbidity and mortality of children in particular. When surface water of river Ganga is used for drinking purpose, removal of undesirable chemical and biological contaminants become an important part of the water purification process. Commonly used methods for water purification are UV- treatment, boiling, chlorination, coagulation, microfiltration, etc. The conventional method of water purification using aluminium sulphate, iron salts add chemicals in drinking water and give rise to problem of deposition of sediment in distribution if not applied at correct dosage (WHO, 2004). Many chemicals and devices used for treatment of water are high-priced and beyond the reach of most people in developing world (Varshney, 1982). So, there is a need of safe, economical, effective and easily available alternative. Many workers are now suggesting using medicinal plants to remove impurities of water as well as to decrease the intensity of microbes found in water. The antimicrobial properties of medicinal plants have been reported by number of workers worldwide (Grosvenor et al. 1995, Adriana et al. 2007, Abu-Shanab 2008, Valle et al., 2015, Gopalakrishnan et al., 2016). The possibility of using medicinal plants that is cost-effective, safe and 
easily available such as $M$. oleifera popularly known as "Sahjan" is increasing (Eilert et al., 1981, Gassenschmidt et al., 1995, Sotheeswaran et al. 2011, Onuoha and Alisa, 2013). M. oleifera is native to India, but it is widely grown in SouthSaharan Africa and South-America (Grabow, 1985). Among the 13 species of Moringa in the family Moringaceae, $M$. oleifera is the most widely cultivated species (Price, 1985, Fahey, 2005). M. oleifera (vernacular name Alruway) "the tree for purifying", used as a vegetable (leaves, fruits, immature pods, flowers and roasted seeds) spice (bark and roots), and cosmetic oil (seeds) (Njoku and Adikwu, 1997, Rebecca et al., 2006, Anwar et al., 2007). All parts of Moringa species show medicinal properties and they are well known to be anti-inflammatory, anti-helminthic, antihypertensive, antibiotic, anti-bacterial, detoxifiers, and immune builders (Thilza et al., 2010). Hence the present study was undertaken to know the ameliorating effect of aqueous extract of Moringa species on the physicochemical and microbial characteristics of Ganga water so that it can be used as an alternative to expensive purification methods of water.

\section{MATERIALS AND METHODS}

Sampling: $M$. oleifera leaves used in the study were collected from Patna Science College campus of Patna University, Patna, Bihar in February, March and April, 2017. Water samples were collected from three Ghats i.e. Kali Ghat (Site 1), Krishna Ghat (Site 2) and N.I.T (National Institute of Technology, Patna) Ghat (Site 3) of the river Ganga in Patna, Bihar in pre-cleaned plastics bottles and were immediately used for the experiments.

Preparation of aqueous extract of $M$. oleifera: Aqueous extract of $M$. oleifera was prepared as per the method of Sowmeyan et al. (2011) with modifications in the quantity of powdered leaves taken to treat poor water quality Ganga. Collected fresh leaves were washed, air dried and grinded to a fine powder and stored in an air tight container for further use. The ground leaves of the plant weighing $0.3 \mathrm{gm}, 0.5 \mathrm{gm}, 0.7 \mathrm{gm}$ and $0.9 \mathrm{gm}$ were suspended in $300 \mathrm{ml}$ of raw Ganga water sample each, to obtain the concentration of $0.1 \%, 0.16 \%$, $0.23 \%$ and $0.3 \%$ of the extract respectively. The suspensions were mixed using magnetic stirrer for about 20 minutes. The suspension was then left undisturbed for about 4 hours followed by centrifugation at $2800 \mathrm{rpm}$ (revolution per minute) for 3 minutes. Finally, supernatants were filtered through muslin cloth, followed by Whatman filter paper no.1. The raw Ganga water (without the ground leaves) was considered as the control for the comparision purpose.

Physicochemical analysis of water samples: The filtrate and the Ganga water were analyzed for the physicochemical parameters such as $\mathrm{pH}$, conductivity, total dissolved solids, total hardness, chloride, alkalinity; using the standard procedures as per APHA, AWWA and WEF (2005). pH was studied by digital $\mathrm{pH}$ meter (model, $\mathrm{pH}$ tester 10 , Eutech instruments, oaklon). Conductivity was measured by digital conductance instrument (model, Eco tester, EC low, Eutech instruments). Estimation of total dissolved solids was done by oven dried method. Total alkalinity was measured by titrating the sample with sulphuric acid taking phenolphthalein and methyl orange as indicator. Total hardness was measured by titrating it with standardized EDTA taking Erichrome Black-T as indicator. Chloride was estimated by argentometric titration method.

Microbiological analysis of water samples: The filtrate and the Ganga water were analyzed for the colony forming units (CFUs) of bacteria by serial dilution standard plant count method using Nutrient Agar Media. The total coliform in filtrate and Ganga water was determined by a statistical estimation called the Most Probable Number (MPN) test performed sequentially in three stages - presumptive, confirmation and complete test using lactose broth, brilliant green lactose, EosinMethylene Blue (EMB) agar medium following standard procedures as per APHA, AWWA and WEF (2005). Colonies of $E$. coli can be differentiated on the basis of small size and the presence of green metallic sheen.

Computation of MPN: MPN of the total coliform bacteria was calculated by using comparing the positive tubes from MC Crady's statistical table and Thomas formula (APHA, AWWA and WEF (2005).

\section{RESULTS AND DISCUSSION}

Effect of extract of $M$. oleifera on $\mathrm{pH}$ : $\mathrm{pH}$ is defined as the intensity of the acidic or basic character of a solution at a given temperature expressed as negative logarithm of hydrogen ion concentration $(\mathrm{pH}=-\log [\mathrm{H}+])($ Paul and Sanyal, 2017). Estimation of $\mathrm{pH}$ in Ganga water is one of the significant parameter in determining quality for portability. The permissible limit of $\mathrm{pH}$ in drinking water ranged from 6.5 to 8.5 (WHO, 2008). The $\mathrm{pH}$ observed at site 1 i.e. Kali Ghat was 8.4, whereas the $\mathrm{pH}$ of site 2 i.e. Krishna Ghat was 8.1 and the $\mathrm{pH}$ of site 3 i.e. NIT Ghat was 8.1; but after using of aqueous leaves extract of different doses, the $\mathrm{pH}$ of water in every site was decreased (Fig. 1). The decrease of $\mathrm{pH}$ in the present study is supported by the study of (Basra et al. 2014), who also observed rapid decrease in $\mathrm{pH}$ in treated sewage water of Faisalabad, Pakistan after 3-4 hour of treatment of aqueous extract of M. oleifera. Its extract contains cellulose, hemicellulose, lignin, and crude fiber. Its matrix network consists of fiber carbonaceous, carboxylic and amino func- 
Paul, D. K. et al. / J. Appl. \& Nat. Sci. 10 (4): 1230 -1237 (2018)

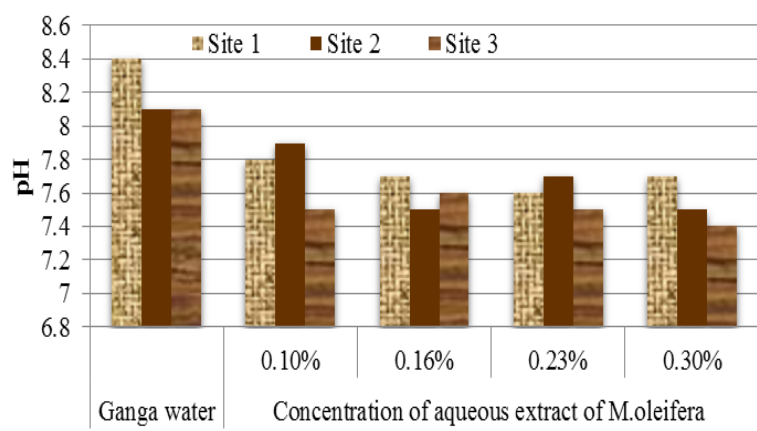

Fig. 1. Effect of different concentrations of aqueous extract of powder leaves of M. oleifera on $\mathrm{pH}$ of Ganga water.

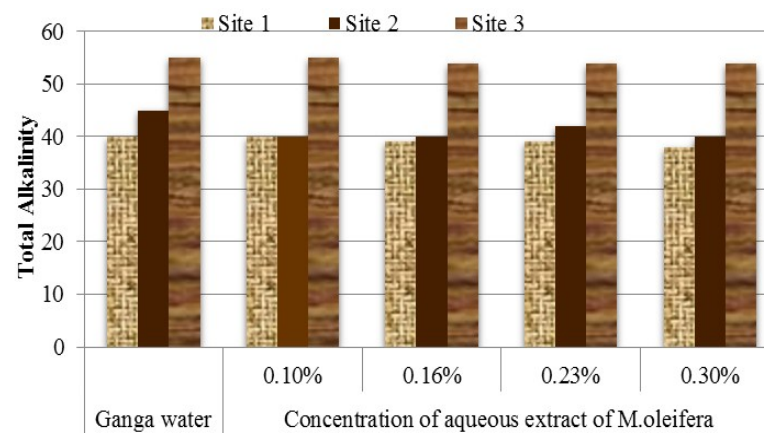

Fig. 2. Effect of different concentrations of aqueous extract of powder leaves of $M$. oleifera on total alkalinity of Ganga water.

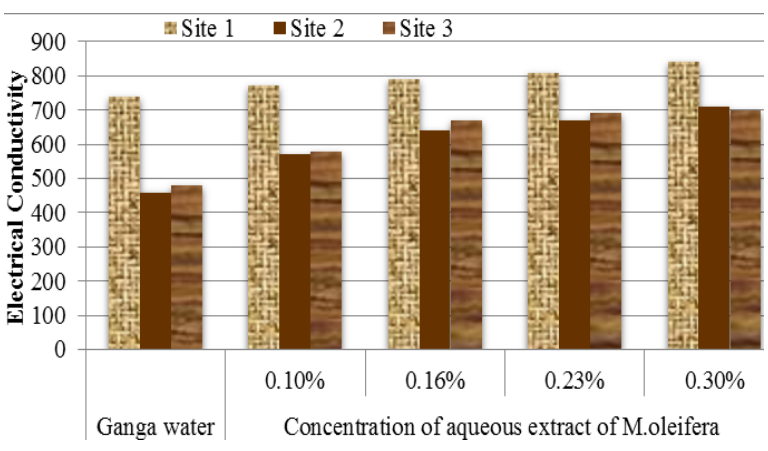

Fig. 3. Effect of different concentrations of aqueous extract of powder leaves of $M$. oleifera on electrical conductivity of Ganga water.

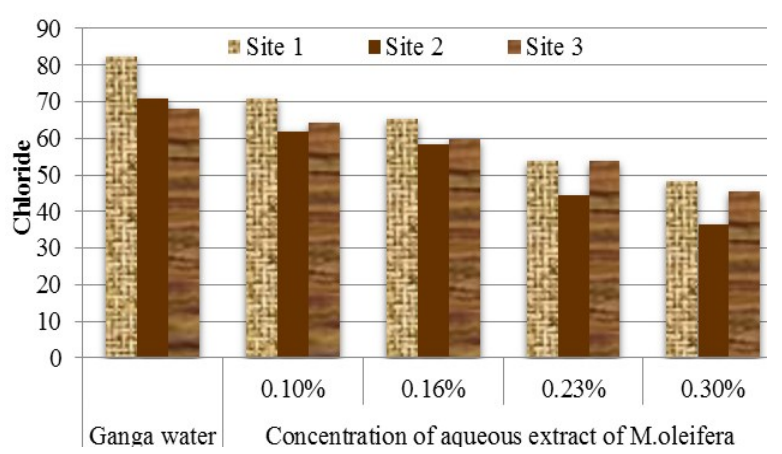

Fig. 4. Effect of different concentrations of aqueous extract of powder leaves of $M$. oleifera on chloride of Ganga water.

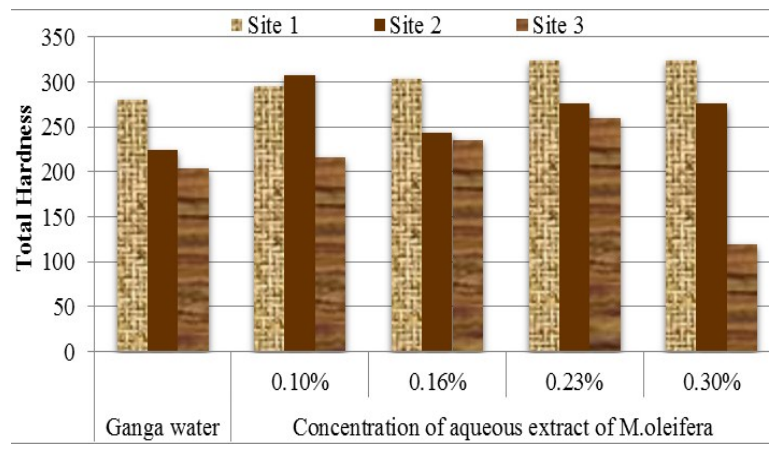

Fig. 5. Effect of different concentrations of aqueous extract of powder leaves of $M$. oleifera on total hardness of Ganga water.

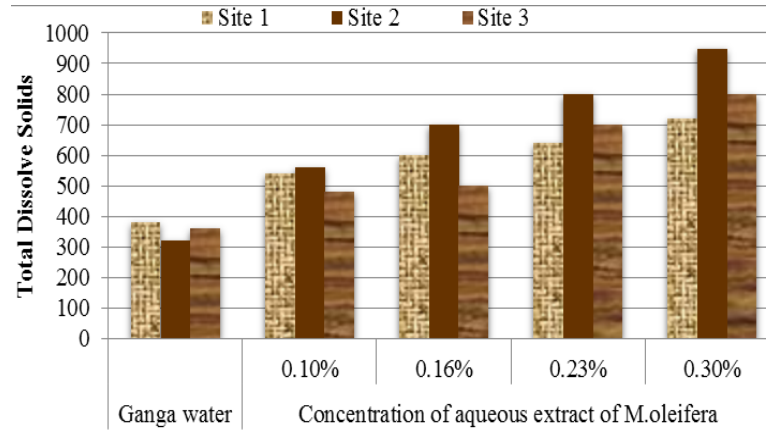

Fig. 6. Effect of different concentrations of aqueous extract of powder leaves of $M$. oleifera on total dissolved solids of Ganga water.

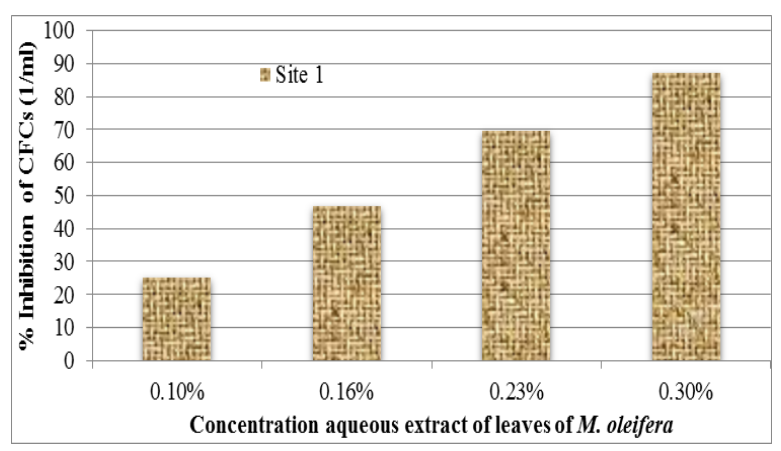

Fig. 7. Effect of different concentrations of aqueous extract of M. oleifera leaves on \% inhibition of CFUs $(1 / \mathrm{ml})$ of Ganga water (Site 1).

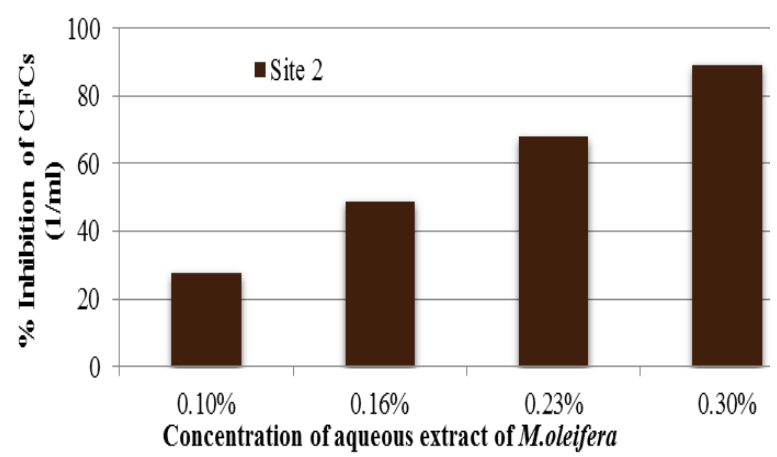

Fig. 8. Effect of different concentrations of aqueous extract of M. oleifera leaves on \% inhibition of CFUs $(1 / \mathrm{ml})$ of Ganga water (Site 2). 
Paul, D. K. et al. / J. Appl. \& Nat. Sci. 10 (4): 1230 -1237 (2018)

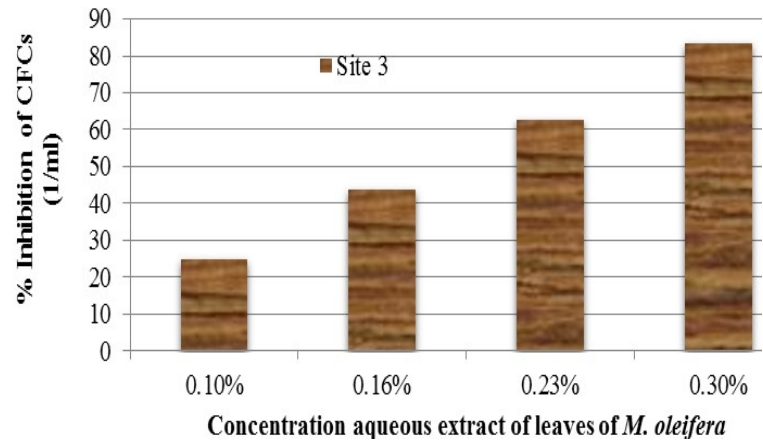

Fig. 9. Effect of different concentrations of aqueous extract of $M$. oleifera leaves on \% inhibition of CFUs $(1 / \mathrm{ml})$ of Ganga water (Site 3).

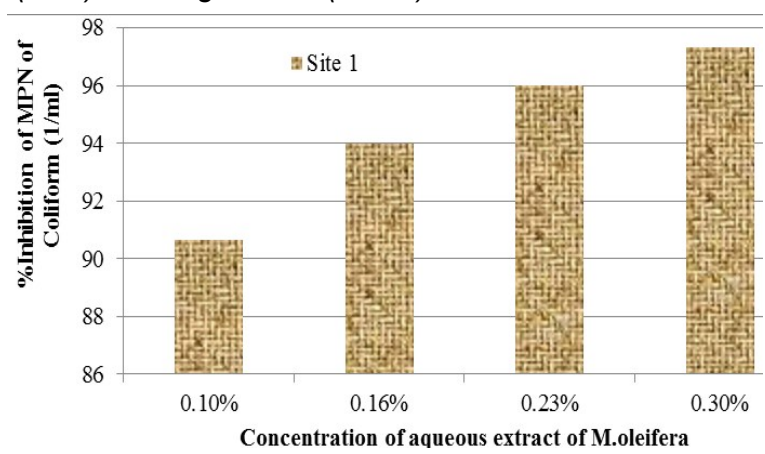

Fig. 10. Effect of different concentrations of aqueous extract of M. oleifera leaves on \% inhibition of MPN of coliform (1/ml) of Ganga water (Site 1).

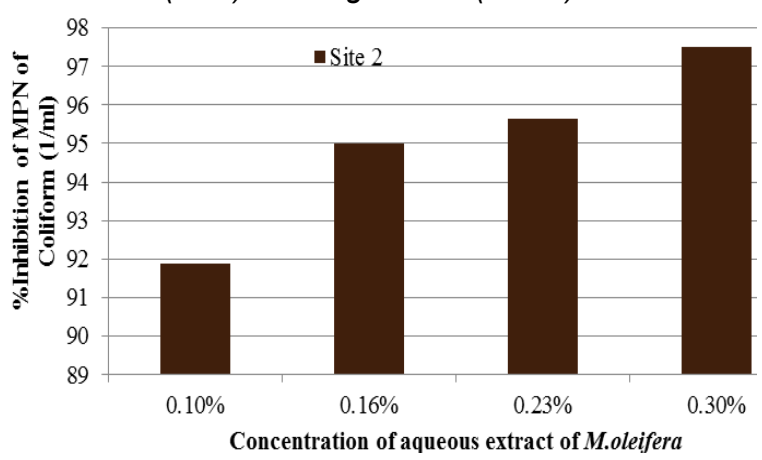

Fig. 11. Effect of different concentrations of aqueous extract of M. oleifera leaves on \% inhibition of MPN of coliform (1/ml) of Ganga water (Site 2).

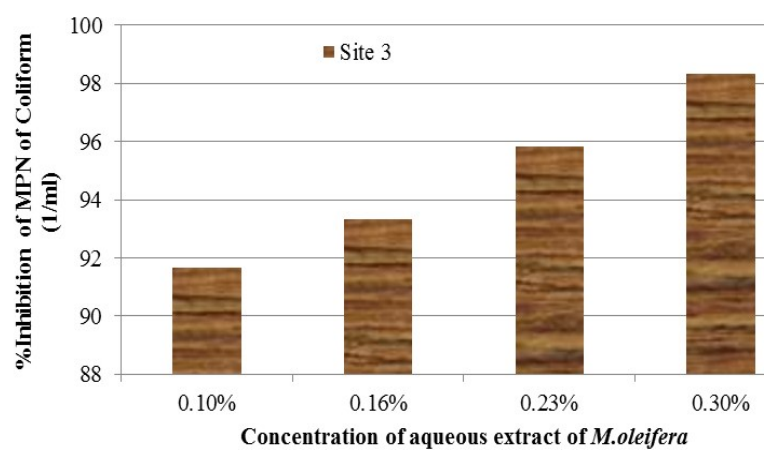

Fig. 12. Effect of different concentrations of aqueous extract of $M$. oleifera leaves on \%inhibition of MPN of coliform (1/ml) of Ganga water (Site 3).

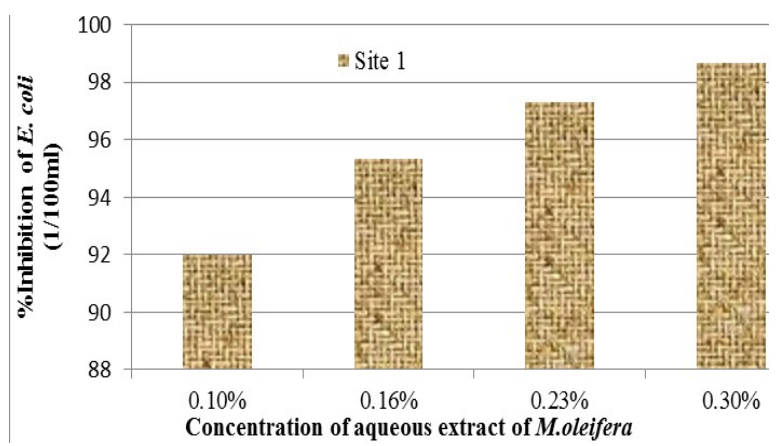

Fig. 13. Effect of different concentrations of aqueous extract of M. oleifera leaves on \% inhibition of Escherichia coli (1/100ml) of Ganga water (Site 1).

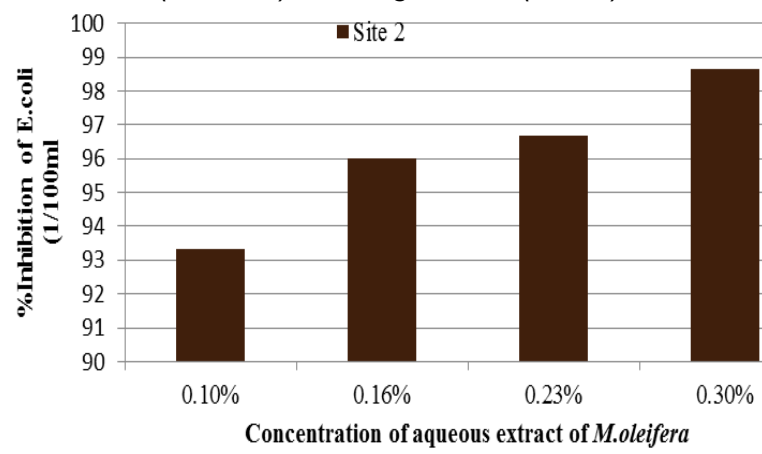

Fig. 14. Effect of different concentrations of aqueous extract of M. oleifera leaves on \% inhibition of Escherichia coli (1/100ml) of Ganga water of (Site 2).

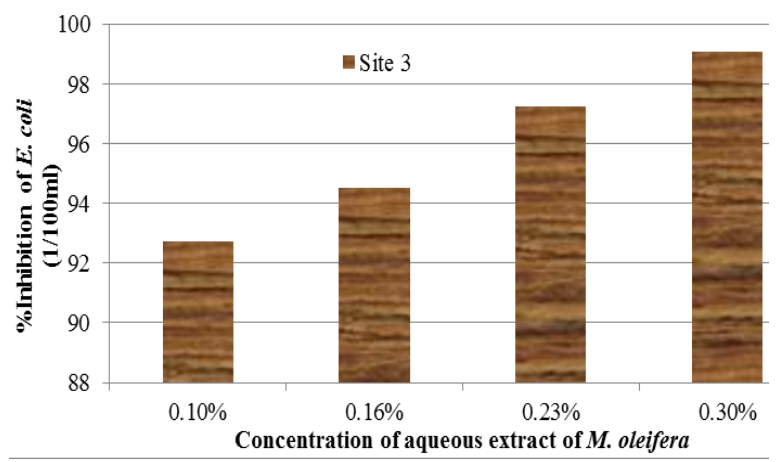

Fig. 15. Effect of different concentrations of aqueous extract of M. oleifera leaves on \% inhibition of Escherichia coli (1/100ml) of Ganga water (Site 3).

tional groups (Akhtar et al., 2007). These functional groups may be dissociated at various $\mathrm{pH}$ values and accordingly take part in the adsorption process (Sinha et al., 2016). Water soluble proteins of $M$. oleifera leaves are effective to maintain the $\mathrm{pH}$ in the range of $5-8$ (Vieira et al. 2010a).

Effect of extract of $M$. oleifera on total alkalinity: Alkalinity refers to the capacity of water or any solution to neutralize acids. It is expression of buffering capacity. Total alkalinity of water is mainly due to cations of calcium, magnesium, sodium and potassium. It is also due to combined carbonate or bicarbonate. The total alkalinity at site 1 i.e. Kali Ghat was $40 \mathrm{mg} / \mathrm{l}$, alkalinity of site 2. i.e. Krishna Ghat is $45 \mathrm{mg} / \mathrm{l}$ and the alkalinity of site 3 
i.e. NIT Ghat was also $55 \mathrm{mg} / \mathrm{l}$ but after using of aqueous leaves extract of different concentration, the values of alkalinity changed slightly (Fig. 2). After treatment with $0.1 \%$ and $0.16 \%$ concentration, the values of alkalinity in Kali Ghat remain unchanged to $40 \mathrm{mg} / \mathrm{l}$. The values of alkalinity slightly decreased when concentration of $0.16 \%$, $0.23 \%$ and $0.3 \%$ is applied. In Krishna Ghat, after treatment values of alkalinity almost remain unchanged, only slight increase in the value was observed application of $0.23 \%$ concentration. While in NIT Ghat the concentration of alkalinity has almost remain unchanged after application of all the concentration of $M$. oleifera. According to the work of (Ndabigengesere and Narasiah, 1998) alkalinity remained almost constant with the use of Moringa. seeds. In this study, it is revealed that leaves extract of $M$. oleifera did not significantly affect the alkalinity.

Effect of extract of $M$. oleifera on electrical conductivity: Electrical conductivity (EC) of the water sample ability depends on the presence of ions, mobility, concentration, and temperature. The permissible limit of EC in drinking water set by WHO is $0-3000 \mu \mathrm{S}$. In this study, the conductivity observed at site 1 i.e. Kali Ghat was 740 $\mu S$, whereas the conductivity of site 2 i.e. Krishna Ghat was $460 \mu S$ and the conductivity of site 3 i.e. NIT Ghat was $480 \mu \mathrm{S}$; but after using of aqueous Moringa leaves extract of different concentrations the values of conductivity were increased in the sample of every site (Fig. 3). The ions concentration in the water is responsible for conductivity value (Postolachi, 2015). Thus, higher the concentration of extract in the solution, higher will be the conductivity. The reaction of the salt with the water is also one of the possible causes for the rise in the reading (Tunggolou and Payus, 2017 and Vieira et al. 2010b).

Effect of extract of $M$. oleifera on chloride: Chlorides are available in all types of waters. Amount of chloride in natural fresh water is generally very low. It is discharged into water through domestic sewage. The permissible limit of chloride in a drinking water set by WHO is $200 \mathrm{mg} / \mathrm{l}$. In this study, the chloride content at site 1 i.e. Kali Ghat was $82.36 \mathrm{mg} / \mathrm{l}$, whereas the chloride content of site 2. i.e. Krishna Ghat was $71 \mathrm{mg} / \mathrm{l}$ and the chloride content of site 3. i.e. NIT Ghat was $68.16 \mathrm{mg} / \mathrm{l}$ but after using of aqueous leaves extract of different doses the chloride content of water sample were decreased (Fig. 4). Sowmeyan et al. 2011 observed that the herbal coagulants have less prospective on removal of chlorides but the present study showed that there is possibility of using $M$. oleifera to get desire value of chloride in water sample. It was observed that leaf extracts decreased the concentration of chloride in Ganga water because cations from the leaf extract attract negatively charged chloride ions present in un- treated water and neutralize the chlorides (Mangale et al., 2012, Patil et al., 2017).

Effect of extract of $M$. oleifera on total hardness: Total hardness is the measurement of mineral content in a water sample that is irreversible by boiling. Hardness is caused due to the divalent metallic cations. The major anions associated with these cations are carbonates, bicarbonates, sulphates and nitrates. According to Indian Standard, 1991, the permissible limit of a total hardness in drinking water is $300 \mathrm{mg} / \mathrm{l}$. In this study, the hardness at site 1 was $280 \mathrm{mg} / \mathrm{l}$, whereas the hardness of site 2 was $224 \mathrm{mg} / \mathrm{l}$ and the hardness of site 3. i.e. NIT Ghat was $204 \mathrm{mg} / \mathrm{l}$. After using aqueous leaves extract of different concentrations, the values of hardness of water sample was increased, but only with the $0.3 \%$ concentration of aqueous leaves extract, the total hardness of water at NIT Ghat was decreased to $120 \mathrm{mg} / \mathrm{l}$ (Fig. 5). (Muyibi and Evison, 1995 and Ndabigengesere and_Narasiah, 1998) observed that a significant hardness removal only obtained at relatively higher concentration. The present study support their conclusion as it exhibit that aqueous extract of Moringa oleifera showed promising results in only one out of three samples with an optimum concentration of $0.3 \%$. According to Ali et al. (2010) and Sinha et al. (2016) as a polyelectrolyte it may therefore be suggested that $M$. oleifera decreased hardness in water through adsorption and interparticle bridging.

Effect of extract of $M$. oleifera on total dissolved solids: Total dissolved solids (TDS) are a measure of the combined content of all inorganic (chiefly calcium, magnesium, potassium, sodium, bicarbonates) and organic substances that are dissolved in a liquid in a molecular, ionized or micro- granular suspended form. A high content of dissolved solid elevates the density of water, reduces solubility of gases (like oxygen) and reduce utility of water for drinking. TDS concentration beyond $500 \mathrm{mg} / \mathrm{l}$, decreases portability and may cause gastrointestinal irritation. According to Indian Standard, 1991, the permissible limit of TDS in drinking water is $100 \mathrm{mg} / \mathrm{l}$. In the present study, the observed value of TDS at site 1 i.e. Kali Ghat was $380 \mathrm{mg} / \mathrm{l}$, at site 2 observed value of TDS was $320 \mathrm{mg} / \mathrm{l}$ and the TDS of site 3. i.e. NIT Ghat was $360 \mathrm{mg} / \mathrm{l}$, but after using aqueous leaves extract of any concentration the TDS of water sample were started to increase, possibly due to presence of fine particles of extract mixed with water sample, which was responsible for the increasing of TDS in water sample (Fig. 6).

Colony forming units (CFUs) and total coliform bacteria: Microorganisms are vital components of all ecosystems whose diversity and abundance are greatly influenced by a wide range of factors (Kondratieff, 1985). For example, presence of "sewage fungus" community in water bodies indi- 
cates high level of organic pollutants. Water pollution due to domestic, food, dairy, agriculture and industrial wastes contain pathogens (disease causing microorganism). They are hazardous to human health if used as drinking water or food preparation. The bacteria present in water provide an estimate of the presence of water borne pathogens. Escherichia coli (E. coli) species are the subset of the coliform bacterial groups that that are found in the intestinal tracts of humans and animals. Their presence is direct indicator of faecal contamination of water. Microbiological tests involve the determination of bacteria growing a colony on a nutrient medium by standard plant count method and estimation of MPN (Most Probable Number) of coliform bacteria.

Standard plate count (SPC): SPC is used to measure the overall bacteriological quality of drinking water. SPC is useful in judging the efficiency in operation of various water treatment processes which determines density of aerobic and facultative anaerobic heterophilic bacteria in water. In this study, the trend of inhibition percentage as well as CFUs against different increasing concentration of powdered extract of Moringa oleifera were seen in all the sites of river Ganga (Fig. 7, 8 and 9). This result showed reduction of CFUs after using of plant extracts.

Among the three sites, maximum inhibition percent of CFUs was observed in Krishna Ghat which subsequently rose from $25.21 \%$ at $0.1 \%$ concentration to $89.36 \%$ at $0.3 \%$ concentration. CFUs of raw water was $468 / \mathrm{ml}$ which decreased to $250 / \mathrm{ml}$, $60 / /$ at concentration of $0.16 \%$ and $0.3 \%$ respectively. Kali Ghat (Site 1) exhibited maximum inhibitory property $(87.17 \%)$ against CFUs at $0.3 \%$ concentration of $M$. oleifera, in comparison to Krishna Ghat (Site 2). At this site CFUs of raw water was $470 / \mathrm{ml}$ which decreased to $340 / \mathrm{ml}, 240 / \mathrm{ml}, 150 / \mathrm{ml}$ and $50 / \mathrm{ml}$ at concentration of $0.1 \%, 0.16 \%, 0.23 \%$ and $0.3 \%$ respectively. At site 3 (NIT Ghat), effectiveness of $M$. oleifera in inhibiting the CFUs was only about $25 \%$ at $0.1 \%$. At $0.7 \%$ the effectiveness rose to $62.5 \%$. At NIT Ghat, $M$. oleifera was most effective $(83.33 \%)$ at concentration of $0.3 \%$. The effectiveness of $M$. oleifera in inhibiting the CFUs was in accordance with the study on water sample collected from Gomti River by Kumar and Gopal, (2008).

Most probable number (MPN) of coliform bacteria: The most probable number (MPN) methods are commonly employed for enumerating coliform bacteria in water. The MPN method of estimation of coliform bacteria (estimation of concentration of target organisms) includes culture and enzyme - substrate techniques. Culture method relies on the detection of gas evolved when coliform bacteria (E.coli) ferment lactose or the presence of turbidity (Enterococci), colony formation per color to detect the target organisms.
MPN of the total coliform bacteria was calculated by comparing the positive tubes from MC Crady's statistical table and Thomas formula (APHA, AWWA and WEF, 2005). The aqueous extracts of $M$. oleifera leaves were assessed to observe antimicrobial activity to inhibit coliform. The increasing trend of inhibition percentage of microbes against different increasing dose of powdered extract of $M$. oleifera was seen in all the sites of river Ganga (Fig. 10, 11 and 12).

The presence of total coliform in surface water comes from poor sanitation system. For total coliform, it is perceived that the maximum number of total coliform $(1600 / 100 \mathrm{ml})$ was found in water samples procured from Krishna Ghat (Site 2). Among the treatments, $M$. oleifera was most effective in inhibition of the total coliform at Site 1 (98.33\% at $0.3 \%$ concentration). The results obtained is in accordance with the findings of (Lea 2010) that the use of Moringa extracts achieves up to $99 \%$ bacterial removal from untreated water. MPN of total bacterial population of untreated water at this site was $1200 / 100 \mathrm{ml}$ which showed decreasing trend to $80 / 100 \mathrm{ml}$ (inhibition percentage was $93.33 \%$ ) and $50 / 100 \mathrm{ml}$ (inhibition percentage was $95.83 \%$ ) at concentration of $0.16 \%$ and $0.23 \%$ respectively. Krishna Ghat also exhibit inhibitory property $(97.5 \%)$ against total coliform at $0.3 \%$ concentration. At this site total coliform of untreated water was $1600 / 100 \mathrm{ml}$ which decreased to $40 / 100 \mathrm{ml}$ at $0.3 \%$ concentration. At Kali Ghat (Site1), effectiveness of $M$. oleifera in inhibiting the total coliform was $90.66 \%$ at $0.1 \%$ concentration. At $0.7 \%$ concentration the effectiveness rose to $96 \%$. At this site total coliform of untreated water was $1500 / 100 \mathrm{ml}$ which decreased to $90 / 100 \mathrm{ml}$ at dose of $0.16 \%$ concentration. Abdullah et al. (2014) treated drinking water with powdered extract of $M$. oleifera seeds in the region of Faisalabad district of Pakistan while Hendrawati et al. (2016) treated groundwater, sampled from a well in Pamulang, Jakrta as well as wastewater, sampled from a textile industry in Karawang, Jakarta. Both the studies revealed that $M$. oleifera can be used as a remedy to slow down the growth of coliform populations of untreated water. Present study showed that the powdered extract of $M$. oleifera have a bactericidal property. The bacterial species which were culture, stop growing back after aqueous extract of $M$. oleifera were added.

MPN of Escherichia coli: It is deduced from the present study that Moringa oleifera has an antibacterial property. Fig. 13, 14 and 15 shows the effect of different doses of aqueous extract of leaves of $M$. oleifera in inhibition of Escherichia coli $(1 / 100 \mathrm{ml})$ of untreated water of three study sites. Among the treatments, extracts of $M$. oleifera was found to be most effective against controlling the E. coli at Site $3(99 \%$ at $0.3 \%$ concentration). After Site 3, Site 2 exhibit maximum inhibito- 
ry property $(98.6 \%)$ against $E$. coli at $0.3 \%$ concentration. At this site total coliform of raw water was $1600 / 100 \mathrm{ml}$ which decreased to $40 / 100 \mathrm{ml}$ at dose $0.3 \%$ concentration. At Kali Ghat, effectiveness of $M$. oleifera in inhibiting the $E$. coli was $92 \%, 95.33 \%$ and $97.33 \%$ at $0.3,0.5$ and $0.7 \mathrm{gm}$ respectively. The increasing trend of inhibition percentage of $E$. coli against different increasing dose of powdered extract of Moringa oleifera was observed in all the sites of river Ganga Nancy and Ezekiel, (2014) treated tap water, stream water and dam water with powdered extract of $M$. oleifera seeds in Kitale town, Kenya while Vieira et. al, (2010b) treated water sample collected from a lake and river of Sobral, Ceará, Brazil. The studies showed that extracts of $M$. oleifera has antimicrobial effects on the species of coliform organism tested, E. coli. Both the studies revealed that $M$. oleifera can be used as a remedy to slow down the coliform populations in untreated water showing bactericidal property. Aqueous extract of $M$. oleifera showed remarkable results in water treatment and can be successfully applied in water treatment instead of conventional method of water treatment which are costly and are in beyond the reach of poor people.

\section{Conclusion}

The present study indicated that aqueous extract of $M$. oleifera leaves were very effective in reduction of $\mathrm{pH}$ and chloride. Efficient reduction (83.33\% to $99.5 \%)$ of bacterial population from water sample by utilizing aqueous extract of $M$. oleifera leaves manifest its use in treating diseases caused by bacteria. The results also revealed that aqueous extract of $M$. oleifera leaves has antibacterial effects on the one species of coliform organisms tested i.e. Escherichia coli. Therefore, it could be concluded that aqueous extract of $M$. oleifera is suitable for improving water quality and may be used instead of the conventional methods of water treatment. The leaves can be used in the areas where people are living in extreme poverty and are drinking contaminated surface water as no facilities are available for the treatment. It is environmental friendly and low-cost water treatment method without exhibiting any toxic effect.

\section{REFERENCES}

1. Abdullah, T., Zahoor, T., Ahmed, W., and Saeed, M. (2014). Effect of Moringa oleifera seed extract on drinking water quality of some selected areas of district Faisalabad. Pakistan Journal of Food Science. 24(1):13 -17

2. Abu-Shanab, B.A., Adwan, G., Adwan, K.M., and Abu-Shanab, F. (2008). Efficacy of aqueous and ethanol extracts of some Palestinian medicinal plants for potential antibacterial activity. Islam Univ. J.Gaza. 16(2):77-86

3. Adriana, B., Almodovarl, A.N.M., Pereiral, C.T., and Mariangela, T.A. (2007). Antimicrobial efficacy of
Curcuma zedoaria extract as assessed by linear regression compared with commercial mouthrinses. Brazilian Journal of Microbiology. 38(3): 440-445.

4. Akhtar, M., Hasany, S.M., Bhanger M.I., and lqbal S. (2007) Sorption potential of Moringa oleifera pods for the removal of organic pollutants from aqueous solutions. Journal of Hazardous Materials. 141(3): 546556.

5. Ali, E.M., Muyibi, S.A., Hamzah, M., Alam, S.M.Z., and Salleh, M.R.M. (2010). Production of Natural Coagulant from Moringa Oleifera Seed for Application in Treatment of Low Turbidity Water. J. Water Resource and Protection. 2, 259-266. http:// www.scrip.org/journal/jwarp).

6. Anwar, F., Latif, S., Ashraf, M., and Gilani, A.H. (2007). Moringa oleifera: a food plant with multiple medicinal uses. Phytotherapy Research. 21(1): 17$25 . \quad$ https://www.ncbi.nlm.nih.gov/pubmed/? term=Anwar.

7. APHA, AWWA and WEF (2005). Standard Methods for the Examinations of Water and Wastewater. A joint publication of the American Public Health Association (APHA), The American Water Works Association (AWWA), and the Water Environment Federation (WEF). $\left(21^{\text {st }} E d\right) .1368$.

8. Basra, S.M.A., Iqbal, Z., Rehman, K.U., Rehaman, H.U. and Ejaz, M.F. (2014). Time Course Changes in $\mathrm{pH}$, Electrical Conductivity and Heavy Metals ( $\mathrm{Pb}, \mathrm{Cr}$ ) of Wastewater Using Moringa oleifera Lam. Seed and Alum, a Comparative Evaluation. Journal of Applied Research and Technology. 12(3): 560-567.

9. Eilert, U., Wolters, B., and Nahrstedt, A. (1981). The antibiotic principle of seeds of Moringa oleifera and Moringa stenopetala. Planta medica. 42(1): 55-61.

10.Fahey, J.W. (2005). Moringa oleifera: A review of the medical evidence for its nutritional, therapeutic and prophylactic properties. Part 1. Trees for Life Journal. 1: 5

11.Fetter, C.W.B. (2011). Obituary-Groundwater. Published by National Groundwater Association. Wiley online library. 49(6) 949-949.

12.Francis, K.A., and Amos, B. (2009). Effectiveness of Moringa oleferia seed as coagulant for water purification. African Journal of Agricultural Research. 4: 119. Vol. 4 (1), 119-123.

13.Gassenschmidt, U., Jany, K., Tauscher, B., and Niebergall, H. (1995). Isolation and characterization of a flocculating protein from Moringa oleifera Lam. Biochemica Biophysica Acta. 43: 477-481.

14.Grabow, W., Slabert, J.L., Morgan, W.S.G., and Jahn, S.A. (1985). Toxicity and mutagenicity evaluation of water coagulated with Moringa oleifera seed preparations using fish, protozoan, bacterial, coliphage, enzyme, and Ames Salmonella assays, Water SA Manuscript. 11(1): 9-14.

15.Grosvenor, P.W., Supriono, A., and Gray, D.O. (1995). Medicinal plants from Riau Province, Sumatra, Indonesia. Part 2: Antibacterial and antifungal activity. J. Ethnopharmacol. 45(2): 97-111.

16.Gopalakrishnan, L., Doriya, K., and Kumar, D.S. (2016). Moringa oleifera: A review on nutritive importance and its medicinal application. Food Science and Human Wellness. 5(2): 49-56.

17. Hendrawati, Y.I.R., Rohaeti, E., Effendi, H, and Darusman, L.K. (2016). The use of Moringa Oleifera seed powder as coagulant to improve the quality of wastewater and groundwater. IOP Conference Se- 
ries: Earth and Environmental Science. 311-10.

18.Iscen, C.F, Emiroglu, O., Ilhan, S., Arslan, N., Yilmaz, V., and Ahiska, S. (2008). Application of multivariate statistical techniques in the assessment of surface water quality in Uluabat Lake. Environmental Monitoring Assessment. 144 (1-3): 269-276.

19.Jaiswal, S.K., Gupta, V.K., Maurya, A., and Singh, R. (2017). Changes in water quality index of different Ghats of Ganges River in Patna. International Journal of Emerging Trends in Science \& Technology. 04 (08): $5549-5555$.

20.Kondratieff, F., and Simmons, Jr.M. (1985). Microbial colonization of seston and free bacteria in an impounded river. Hydrobiologia. 128: 127-133.

21.Kumar, S., and Gopal, K. (1999). Screening of plant species for inhibition of bacterial population of raw water. Journal of Environmental Science and Health. Part A. Toxic Hazardous Substances and Environmental Engineering. 34(4): 975-987.

22.Lea, M. (2010). Bioremediation of turbid surface water using seed extract from Moringa oleifera Lam. (Drumstick) tree. Currents protocols in Microbiology. John Wiley \& Sons, Inc. 16(1). Pp 16:1G.2.1 1G.2.14.

23.Mangale, S.M., Chonde, S.G., and Raut P.D. (2012). Use of Moringa Oleifera (Drumstick) Seed as Natural Absorbent and an Antimicrobial Agent for Ground Water Treatment. Research Journal of Recent Sciences, 1(3): 33-39.

24.Muyibi, S.A., and Evison, L.M. (1995). Optimizing physical parameters affecting coagulation of turbid water with Moringa oleifera seeds. Water Research. 29(12): 2689-2695.

25.Nancy, B.N., and Ezekiel, Y.K. (2014). Effects of Moringa Oleifera seeds on Escherichia coli, Enterobacter aerogenes, $\mathrm{pH}$ and turbidity in water from selected sources in Kitale town, Kenya. Conference Paper.

26.Ndabigengesere, A., and Narasiah, K.S. (1998). Quality of water treated by coagulation using Moringa oleifera seeds. Water Research. 32(3): 781-791.

27.Njoku, I., and Adikwu, P. (1997). Toxicological studies reveal the absence of mycotoxins in Northeastern Nigeria. Int. J. Food Sci Nutrition. 51(3): 195-208.

28. Onuoha, S.C., and Alisa, C.O. (2013). Antimicrobial Potential of Leaf juice and Extracts of Moringa oleifera lam against some Human pathogenic Bacteria. Journal of Pharmacy and Biological Sciences (IOSRJPBS). Volume 5 (4): 37-42.

29.Patil, R.R., Jagadale, S.S., Gaikwad A.A., Mane A.V., Vathar, T.V., Anekar, N.R,. and Awasare, S.D. (20170. Use of Moringa Oleifera (Drumstick) seed as Natural Coagulant for Well \& Bore well Water Treatment. International Journal of Engineering Research and Technology. 10 (1): 35-40.

30.Paul, D.K., and Sanyal, S. (2017). Assessment of seasonal variation of physicochemical characteristics of Sanjay Gandhi Jaivik Udyan pond, Patna (Bihar) India. Journal of Patna Science College. 5:91-107.

31.Postolachi, L., Rusu, V., Lupascu, T. and Maftuleac, A. (2015). Improvement of coagulation process for the Prut River water treatment using aluminum sulphate. Chem. J. Moldova, 10: 25-32.

32.Price, M.L., (1985). Revised by Davis K. (2000). The Moringa Tree. Echo Technical Note. http://
www.pkdiet.com/pdf/food/drumstick/Morings1.PDF.

33.Rebecca, H., Sharon, M., Arbainsyah, A., and Lucienne, D. (2006). Moringa oleifera: medicinal and socio-economic uses. International Course on Economic Botany. National Herbarium Leiden, Netherlands. $2-6$.

34.Sinha, S.N., Paul, D., and Biswas. K. (2016). Effects of Moringa oleifera Lam. and Azadirachta indica, A. Juss. leaf extract in treatment of tannery effluent. Our Nature. 14(1): 47-53.

35.Sood, A., Singh, K., Pandey, P., and Sharma, S. (2008). Assessment of bacterial indicators and physicochemical parameters to investigate pollution status of Gangetic river system of Uttarakhand (India). Ecolological Indicators. 8: 709-717.

36.Sowmeyan, R., Santosh, J., and Latha, R. (2011). Effectiveness of herbs in community water treatment. International Journal of Biochemistry and Bioinformatics. 1(11): 297-303.

37. Sotheeswaran, S., Nand, V., Maata, M, and Kanayathu, K. (2011). Moringa oliefera and other local seeds in water purification in developing countries. Research Journal of chemistry and environment. 15 (2): 135 - $138 . \quad \mathrm{https}: / / \mathrm{www} \cdot$ researchgate.net/ publication/255484408_Moringa_oleifera_and_other _local_seeds_in_water_purification_in_developing_c ountries.

38.Thilza, I.B, Sanni, S., Zakari, A.I, Sanni, F.S., Muhammed, T., and Musa, B.J (2010). In vitro antimicrobial activity of water extract of Moringa oleifera leaf stalk on bacteria normally implicated in eye disease. Academia Arena. 2(6): 80-83.

39.Tunggolou, J. and Payus, C. (2017). Application of Moringa oleifera Plant as Water Purifier for Drinking Water Purposes. Journal of Environmental Science and Technology. 10: 268-275.

40.Valle, D.L., Andrade, J.I., Puzon, JJM., Cabrera, E.C., and Windell, L.R. (2015). Antibacterial activities of ethanol extracts of Philippine medicinal plants against multidrug-resistant bacteria. Asian Pacific Journal of Tropical Biomedicine. 5(7): 532-540.

41.Varshney, C.K. (1982). Water Pollution and Management, Review. South Asian Publishing. New Delhi. 152

42.Vieira, A.M.S., Vieira, M.F., Silva, G.F., Araujo, A.A., Fagundes-Klen, M.R., Veit, M.T., and Bergamasco, R. (2010a). Use of Moringa oleifera seed as a natural adsorbent for wastewater treatment. Water Air Soil Pollution. 206 (1-4): 273-281.

43.Vieira, G.H.F., Mourao, J.A., Angela, A.M., Costa, R.A., and Vieira. R.H.S.F. (2010b). Antibacterial effect (In vitro) of Moringa oleifera and Annona muricate against Gram positive and Gram negative bacteria. Rev. Inst. Med. Trop. Sao Paulo. 52(3):129-132

44.WHO (2008). Guidelines for drinking-water quality [Electronic resource]. Third edition: incorporating 1st and 2nd addenda, Vol.1. Geneva, World Health Organization.

45.Willey, J.M., Sherwood, L.M., and Woolverton, C.J. (2008). Prescott, Harley, and Klein's Microbiology. McGraw Hill, NY. Edition $7^{\text {th }} .123-156$.

46.World Health Organisation. (2004). Chemicals from water treatment and distribution - Retrieved October 26, 2018 from http://www.who.int>dwq . 